\title{
CURRENT STATUS AND ANALYSIS OF CHINA'S REGIONAL AND BILATERAL TRADE AGREEMENTS
}

\section{Korol M. M.}

\section{INTRODUCTION}

The strategic partnership as a type of bilateral relations has a deep character, which is not limited only by the foreign trade relations, but has certain systemic features and demonstrates a dynamic development both on quantitative and institutional level with the general aim to harmonize the bilateral economic development. As said above, the regional economic integration must take place at the initial stages of strategic partnership between countries. The secondary objective of strategic partnerships is to ensure the structural and balanced economic development of partner countries. From the point of view of internationalization, the definition of strategic partnership is considered as a level of cooperation between countries, within which the common goals are achieved and common interests are agreed. At the regional level of the systemic hierarchy, strategic partnership is considered as the collaboration between companies and organizations, that share common goals and strive to achieve them ${ }^{1}$.

In the further research, we consider it advisable to focus on the strategic cooperation in the spheres of economy and trade. One of the key events in China's foreign trade policy was joining an international organization such as World Trade Organization (WTO) on December 11, 2001, which, however, was preceded by a lengthy negotiation process. In particular, the WTO has required significant changes in the Chinese economy.

According to the WTO Dispute Settlement System, from January 1, 2016 to March 31, 2018, China was involved in six cases as a respondent and two as a complainant.

After accession to the WTO China has begun to work more actively on regional and bilateral trade agreements.

Authorities say the strategy is to accelerate the implementation of free trade agreements (FTA) is an important element of the new round of trade liberalization in China.

${ }^{1}$ Висоцька М. Аналіз основних тенденцій розвитку економічних відносин між Україною та Китаєм / М. Висоцька, А. Аль Атті // Стратегія розвитку України. Економіка, соціологія, право. - 2013. - № 4. - С. 14-20, с. 14. 
During 2001-2018, China signed 18 free trade agreements (3 of which were revised and upgraded) with 24 countries or regions (Table 1): Maldives; Georgia; Australia; Republic of Korea; Switzerland; Iceland; Costa Rica; Peru; Singapore; New Zealand; Chile; Pakistan; ASEAN; Hong Kong, China; Macau, China; ASEAN (upgraded); Chile (upgraded); Singapore (upgraded).

Table 1

Free Trade Agreements and Contract Dates ${ }^{2}$

\begin{tabular}{|c|c|}
\hline \multicolumn{2}{|c|}{ Free Trade Agreements } \\
\hline Subjects & Contract Date \\
\hline Maldives & December 2017 \\
\hline Georgia & May 2017 \\
\hline Australia & December 2015 \\
\hline Republic of Korea & June 2015 \\
\hline Switzerland & July 2013 \\
\hline Iceland & April 2013 \\
\hline Costa Rica & April 2010 \\
\hline Peru & April 2009 \\
\hline Singapore & October 2008 \\
\hline New Zealand & April 2008 \\
\hline Chile & November 2005 \\
\hline Pakistan & November 2006 \\
\hline ASEAN & November 2004 \\
\hline Hong Kong, China (CERA) & June 2003 \\
\hline Macau, China & October 2003 \\
\hline ASEAN (upgraded) & November 2015 \\
\hline Chile (upgraded) & November 2017 \\
\hline Singapore (upgraded) & November 2018 \\
\hline
\end{tabular}

Analyzing the table 1 it is worth noting that after 2013, China has stepped up its activity in contracting or updating its free trade agreements. The main

${ }^{2}$ China's Free Trade Agreements [Електронний pecypc]. - 2019. - Режим доступу до pecypcy: http://fta.mofcom.gov.cn/english/fta_qianshu.shtml] 
reason, in our view, is the Global Chinese Initiative "Belt and Road Initiative" (which began its operation in 2013), which was expected to strengthen relations with as many countries as possible, which will be discussed later.

15 Free Trade Agreements are under discussion (Table 2): Comprehensive Regional Economic Partnership; Gulf Cooperation Council; Japan-South Korea; Sri Lanka; Israel; Norway; Pakistan (at the 2nd stage); New Zealand (upgraded); Mauritius; Moldova; Panama; Republic of Korea (at the 2nd stage); Palestine; Peru (upgraded).

Table 2

Free Trade Agreements (Under Discussion) and Discussion Start Date ${ }^{3}$

\begin{tabular}{|c|c|}
\hline \multicolumn{2}{|c|}{ Free Trade Agreements (under discussion) } \\
\hline Subjects & Discussion Start Date \\
\hline Comprehensive regional economic partnership & May 2013 \\
\hline Gulf Cooperation Council & July 2004 \\
\hline Japan-South Korea & August 2013 \\
\hline Sri Lanka & August 2013 \\
\hline Israel & March 2016 \\
\hline Norway & September 2008 \\
\hline Pakistan (Stage 2) & December 2016 \\
\hline New Zealand (upgraded) & November 2016 \\
\hline Mauritius & November 2016 \\
\hline Moldova & May 2017 \\
\hline Panama & November 2017 \\
\hline Republic of Korea (at the 2nd stage) & December 2017 \\
\hline Palestine & July 2018 \\
\hline Peru (upgraded) & November 2016 \\
\hline
\end{tabular}

From the table 2, it is clear that after 2013, the number of free trade agreements under discussion has been also increasing.

A certain preferential trade agreement was signed in 1975, known as "Asia-Pacific Trade Agreement". This initiative of the United Nations Economic and Social Commission for Asia and the Pacific is a preferential trade agreement among developing countries. Since September 1, 2006, the results of the third round of tariff reduction negotiations have been successfully implemented by all members of APTA ${ }^{4}$.

${ }^{3}$ Free Trade Agreements under Negotiation [Електронний ресурс]. - 2019. - Режим доступу до ресурсу: http://fta.mofcom.gov.cn/english/fta_tanpan.shtml

${ }^{4}$ Asia-Pacific Trade Agreement [Електронний pecypc]. - 2018. - Режим доступу до pecypcy: http://fta.mofcom.gov.cn/topic/enpacific.shtml. 
On September 12-14, 2018, the 53rd meeting of the Standing Committee of the Asia-Pacific Trade Agreement and related meetings were held in Seoul (South Korea) to discuss issues such as trade in services, investment, trade facilitation rules. It should be noted that this is the first meeting of the Standing Committee after the implementation of the 4th round of tariff concession negotiations, which took place on July $1,2018 .^{5}$

During 2018-early 2019, China also worked in the following areas:

\section{Free Trade Agreement with Georgia}

The Free Trade Agreement between the Government of the People's Republic of China and the Government of Georgia came into force on January 1, 2018 and it is the first free trade agreement that China has signed with Eurasian countries.

After the agreement had come into force, Georgia imposed zero tariffs on $96.5 \%$ of China's products, and China imposed a zero tariff on $93.9 \%$ of Georgian products, $90.9 \%$ of which had zero tariffs at once and the remaining $3 \%$ would gradually to decrease to zero for the next 5 years ${ }^{6}$.

From January 1, 2018, Georgian wine, mineral water, honey, tea, fruits, vegetables and agricultural products will be exported to China at zero tariffs. By taking the opportunity to reach this agreement, China and Georgia will comprehensively improve the level of practical cooperation between them, thus promoting the common prosperity ${ }^{7}$.

As a result, in 2018, China imported \$ 53.6 million of Georgian wine and took the 3rd place in the import of grapes in Georgia. Last year, 7,585,407 bottles of Georgian wine were exported to China, which is of $43 \%$ more, compared to $2016^{8}$.

\section{Free Trade Agreement with the Republic of Korea}

On March 22, 2018, the 2nd meeting of the Committee on Free Trade between China and the Republic of Korea took place. Both sides appreciated the positive role of FTAs in facilitating bilateral trade and investments and exchanged views on the implementation of FTAs. They decided that they would

${ }^{5}$ The 53rd Asia-Pacific Trade Agreement Standing Committee Meeting and Related Panel Meetings Held in South Korea [Електронний pecypc]. - 2018. - Режим доступу до ресурсу: http://fta.mofcom.gov.cn/enarticle/enpacific/enasiapacificnews/201809/38904_1.html.

${ }^{6}$ China-Georgia FTA Comes into Force Today [Електронний ресурс]. - 2018. - Режим доступу до ресурсу: http://fta.mofcom.gov.cn/enarticle/chinageorgiaen/chinageorgiaennews/ 201801/36885_1.html.

${ }^{7}$ Georgia-China free trade deal comes into play from January 2018 [Електронний pecypc]. - 2018. - Режим доступу до ресурсу: http://agenda.ge/en/news/2018/29

${ }^{8}$ China ranks 3rd for Georgia's wine exports in 2018 [Електронний ресурс]. - 2019. Режим доступу до ресурсу: http://www.xinhuanet.com/english/2019-01/05/c_137720361.htm. 
go the way of leaders and negotiate the specific technical problems, with the further implementation of preferential measures and better benefits for the two countries and their people.

The first tariff cut was officially announced on December 20, 2015. Since then, the two sides have cut tariffs four times and zero-tariff products have covered $50 \%$ of bilateral trade ${ }^{9}$

In 2018, China ranks the 1st place in South Korea's exports and is worth \$ 162.2 billion. The United States (26.8\% of South Korea's total exports). During the same year, South Korea experienced the highest trade surpluses within three countries, including China $(25.8 \%)^{10}$.

\section{Free Trade Agreement with Iceland}

September 18-19, 2018 The 3rd Joint Committee on Free Trade between China and Iceland took place in Iceland. At the meeting, both sides praised the achievements of the Free Trade Agreement. They agreed that the implementation of their free trade agreement was widespread for the people and businesses of the two countries and deepened bilateral economic ties.

They also agreed to further FTA cooperation, encourage enterprises to fully implement the FTA preferential policy, and facilitate the development of bilateral economic and trade cooperation to strengthen economic and trade relations between China and Iceland and trade relations between China and European countries ${ }^{11}$.

In 2018, the Iceland's exports to China are totaled \$ 144.3 million or $2.6 \%$ of its total exports ${ }^{12}$.

\section{Free Trade Agreement with New Zealand}

On September 10-13, 2018, the 5th round of free trade zone negotiations with China and New Zealand took place in Beijing. Both sides consulted extensively on issues relating to technical barriers of trade, rules of passage, trade in services, e-commerce, the environment and public procurement. A new FTA negotiation process between China and New Zealand was officially launched in November 2016. The renovation of the FTA will further promote

${ }^{9}$ The 2nd Joint Commission on China-ROK FTA Held in Seoul [Електронний ресурс]. 2018. - Режим доступу до ресурсу: http://fta.mofcom.gov.cn/enarticle/enkorea/enkoreanews/ 201808/38460_1.html.

${ }^{10}$ South Korea's Top Trading Partners [Електронний ресурс]. - 2019. - Режим доступу до ресурсу: http://www.worldstopexports.com/south-koreas-top-import-partners/.

${ }_{11}$ The 3rd Meeting of Joint Committee of China-Iceland FTA Held in Iceland [Електронний ресурс]. - 2018. - Режим доступу до ресурсу: http://fta.mofcom.gov.cn/enarticle/ eniceland/enicelandnews/201809/38980_1.html

12 Top Iceland Exports [Електронний ресурс]. - 2019. - Режим доступу до ресурсу: http://www.worldsrichestcountries.com/top-iceland-exports.html 
economic and trade relations between China and New Zealand, as well as, enhance bilateral economic and trade cooperation. ${ }^{13}$

New Zealand's exports to China have risen since the first Free Trade Agreement (2008) was signed. In 2018, tariffs have been eliminated for more than $97 \%$ of New Zealand's exports to China.

Currently, China is New Zealand's largest trading partner with bilateral trade worth over $\$ 27$ billion $^{14}$.

\section{Free Trade Agreement with ASEAN (upgraded)}

On March 11-15, 2018, the 11th Joint Commission on the updating of the FTA between China and the ASEAN countries took place in Beijing.

At the meeting, both sides praised the FTA of China and ASEAN for its positive impact on people and business, especially since the progress of the implementation of the updated Free Trade Agreement between China and ASEAN. Negotiations were also held on the exchange of experience and practice in the field of trade and e-commerce promotion.

Both sides agreed to strengthen the FTA cooperation, take full advantage of preferential policies and raise bilateral trade and economic cooperation into a new level.

China has been ASEAN's leading trading partner for 10 years, and ASEAN is China's third largest trading partner, after the European Union and the US for eight years. Implementation of the Free Trade Agreement is the basis for consolidating and developing a strategic partnership between China and ASEAN $^{15}$.

In 2018, bilateral trade between China and ASEAN increased by $14.1 \%$ to a record $\$ 587.87$ billion. A number of key factors, which have contributed to the strengthening of economic relations between China and ASEAN. Among the main are the following:

1) a rapid economic growth in both ASEAN and China;

2) the creation of a Free Trade Area between China and ASEAN, which has substantially removed the tariff barriers in goods trade between China and ASAN since 2010;

${ }^{13}$ The 5th Round of Upgrading Negotiation of China-New Zealand Free Trade Agreement Held in Beijing [Електронний pecypc]. - 2018. - Режим доступу до ресурсу: http://fta.mofcom.gov.cn/enarticle/ennewzealand/ennewzealandnews/201809/38897_1.html

${ }^{14}$ New Zealand-China FTA overview [Електронний ресурс]. - 2018. - Режим доступу до ресурсу: https://www.mfat.govt.nz/en/trade/free-trade-agreements/free-trade-agreements-inforce/china-fta/nz-china-fta-overview/.

${ }^{15}$ The 11th Joint Commission on China-ASEAN FTA Held in Beijing [Електронний pecypc]. - 2018. - Режим доступу до ресурсу: http://fta.mofcom.gov.cn/enarticle/enasean/ chianaseannews/201803/37518_1.html. 
3) the consumer markets of both China and ASEAN have grown rapidly over the last decade, driving the demand for a wide range of imported goods and services. Analyzing the investment sector, there are also positive results: by the end of 2018, China has invested \$ 89.01 billion to ASEAN, and ASEAN invested \$ 116.7 billion to China, which has increased bilateral investment for 22 times in 15 years, especially as China's investments to ASEAN began to flow faster. ${ }^{16}$

In 2018, Indonesia's trade with China grew most rapidly from the 10 ASEAN member countries by $22.2 \%$ to $\$ 77.4$ billion. In particular, sales in China from Indonesian imports rose to $19.6 \%$, which is the second largest indicator of sales of China's imports. In 2018, China and ASEAN commemorated the 15th anniversary of the Strategic Partnership, and in November 2018, at the 21st China-ASEAN Summit, both sides announced the 2030 China-ASEAN Strategic Partnership, setting out medium- and long-term plans for the future cooperation.

ASEAN is a key focus for Belt and Road construction, and it was in Indonesia where the Chinese President proposed an important initiative to create the 21st Century Silk Road in 2013. ${ }^{17}$

The above data and facts indicate that China and ASEAN are not only good neighbours but good friends. China is also one of ASEAN's most important trading and investment partners, and vice versa. Trade relations between China and ASEAN are in a complete harmony.

\section{Free Trade Agreement with Chile (upgraded)}

On March 1, 2019, the updated Free Trade Agreement between the Government of the People's Republic of China and the Government of the Republic of Chile entered into force. China has gradually phased out some tariffs on wood products over three years, and Chile has abolished tariffs on textiles, clothing, household appliances and sugar. Products that both sides will sell at zero tariff, will reach $98 \%$. The China-Chile Free Trade Area will become China's FTA with the highest level of open trade.

In terms of trade in services, both sides will expand and increase the number and level of service trade commitments. China will continue to expand in more than 20 sectors, including commercial legal services, entertainment and distribution. Chile has pledged to open up higher levels in more than 40 sectors, including express delivery, transportation and construction. In addition, the

${ }^{16}$ ASEAN-China trade boosting growth [Електронний ресурс]. - 2018. - Режим доступу до ресурсу: http://global.chinadaily.com.cn/a/201811/19/WS5bf1f6a6a310eff303289619.html

${ }^{17}$ China and ASEAN doing well on economic, trade cooperation [Електронний ресурс]. 2019. - Режим доступу до ресурсу: https://www.thejakartapost.com/academia/2019/01/31/chinaand-asean-doing-well-on-economic-trade-cooperation.html 
Protocol has also been revised and supplemented by sections including rules of origin, economic and technical cooperation, as well as, new rules on e-commerce, competition, environment and trade ${ }^{18}$.

In 2018, the bilateral trade between China and Chile reached $\$ 42.8$ billion, which is $24 \%$ more than the previous year. This accounts for almost a third of Chile's total foreign trade ${ }^{19}$.

\section{Free Trade Agreement with Singapore (upgraded).}

On November 5, 2018, a meeting between China and Singapore took place at the first largest exhibition of imported goods and services, "China International Import Expo", where they jointly announced the completion of negotiations to update the existing Free Trade Agreement between China and Singapore. Both parties will sign the protocoll of the Government of the PRC and the Government of the Republic of Singapore after the completion of the demanding internal procedures ${ }^{20}$.

In 2018, Singapore's exports to China totaled $\$ 50.4$ billion or $12.2 \%$ of its total exports. However, in February 2019, Singapore's exports declined by $8.5 \%$ compared to last year due to the decline in electronic and non-electronic traffic, in turn, due to the China-US trade war. This was its worst performance since October 2016, when it was down by $12 \%$.

Overall, in 2019, China announced that it will start reducing or lowering import tariffs for 706 products starting from January 1, with the aim of reducing consumer's spending.

While the first two rounds of tariff cuts in China were mainly focused on consumer's goods and manufactured goods, the last round affects a wide range of commodities such as cotton, fur, some pharmaceutical raw materials, and will continue to temporarily reduce tariffs on products such as aircraft engines, welding jobs and natural resources.

In addition, China will introduce lower ordinary tariffs in accordance with previously agreed trade agreements with 23 countries and territories,

${ }^{18}$ The Protocol Upgrading China-Chile Free Trade Agreement Comes into Force Today [Електронний ресурс]. - 2019. - Режим доступу до ресурсу: http://fta.mofcom.gov.cn/ enarticle/enchile/enchilenews/201903/39927_1.html

${ }^{19}$ China-Chile FTA Upgraded, New Opportunities for Investors [Електронний ресурс]. 2019. - Режим доступу до ресурсу: https://www.china-briefing.com/news/china-chile-ftaupgraded-market-opportunities-investors/

${ }^{20}$ China and Singapore Sign Protocol to Upgrade the Free Trade Agreement [Електронний pecypc]. - 2018. - Режим доступу до ресурсу: http://fta.mofcom.gov.cn/enarticle/singaporetwoen/ singaporetwoennews/201811/39360_1.html

${ }^{21}$ Biggest fall in Singapore exports in over two years [Електронний ресурс]. - 2019. Режим доступу до ресурсу: https:/www.straitstimes.com/business/economy/biggest-fall-in-sporeexports-in-over-two-years 
including: New Zealand, Peru, Costa Rica, Switzerland, Iceland, South Korea, Australia and Georgia ${ }^{22}$.

Let us analyze in more detail the concept of the "Belt and Road Initiative" as China's strategically important global economic project.

The concept of the "Belt and Road Initiative" is a strategic project initiated in 2013 by the President of China Xi Jinping during his visits to Kazakhstan and Indonesia with the purpose of restoring ancient trade routes (previously extending across Asia and Europe). According to this document, it is a network of roads, railways, oil pipelines, power grids, ports and other infrastructure projects designed to connect China to world trade ${ }^{23}$.

The BRI is comprised of two related projects (Figure 1) and covers almost 65 countries, with $63 \%$ of the planet's population, with an estimated economic scale of US \$ 21 trillion.

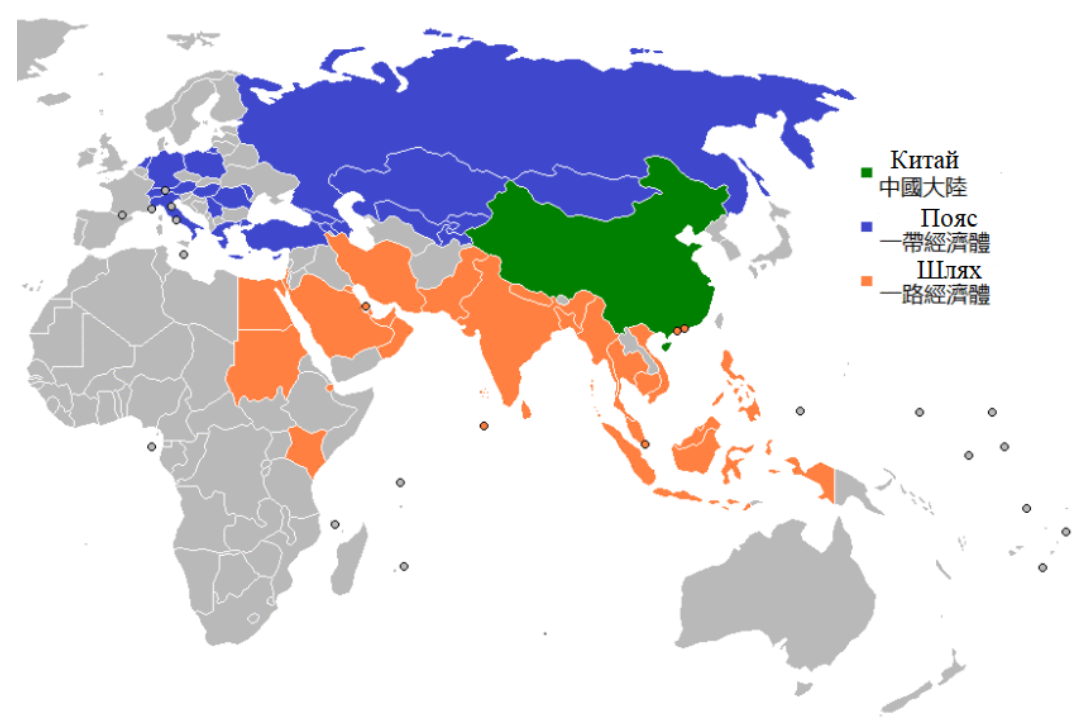

Fig. 1. Global Chinese "Belt and Road Initiative" 24

${ }^{22}$ New Tariff, Export Duty Cuts in China for 2019 [Електронний ресурс]. - 2019. Режим доступу до ресурсу: https://www.china-briefing.com/news/new-tariff-export-duty-cutschina-2019-wide-variety-products-affected/

${ }^{23}$ What is One Belt, One Road in China? [Електронний ресурс]. - 2017. - Режим доступу до ресурсу: https://www.quora.com/What-is-One-Belt-One-Road-in-China

${ }_{24}$ Один пояс, один шлях [Електронний ресурс]. - 2018. - Режим доступу до ресурсу: http://agora-web.jp/archives/2035163.html 
China is highlighted in green, the territory where Belt Initiative is implemented - blue, and the Road is orange. Let's analyze in more detail the picture above.

1. The Belt, also known as the Silk Road Economic Belt, is the creation of three trans-Eurasian economic corridors: the North (China - Central Asia Russia - Europe), the Central (China - Central and West Asia - the Persian Gulf and the Mediterranean). sea) and the south (China - Southeast AsiaSouth Asia - Indian Ocean). It is also a network of land road and rail routes, oil and gas pipelines, as well as other infrastructure projects that will go from Xi'an in central China through Central Asia and to Rotterdam and Venice.

2. The Road, also known as the 21st Century Silk Road, is the creation of two maritime routes: one route from China's coast through the South China Sea to the South Pacific, the other involves the connection of coastal regions of China and Europe across the South China Sea and the Indian Ocean.

It is also a network of ports and other infrastructure projects in the coastal regions of South and Southeast Asia, East Africa and the Northern Mediterranean. Infrastructure projects can play a constructive role in the regional economic architecture and help strengthen political institutions in the region, which will generally reduce incentives and opportunities for terrorist movements.

Also, the elements of this initiative $\operatorname{are}^{25}$ :

3. China-Pakistan Economic Corridor.

4. China-Bangladesh-India-Myanmar Economic Corridor.

The reasons for the creation of the "Belt and Road Initiative" for China include:

1) China's intention to develop its international influence, since despite its economic strength, it is not a member of the G7 countries. In this way, the BRI will allow China to have greater regional influence;

2) China's GDP has slowed down in recent years, even though its development is faster than in other countries. This initiative will serve as another significant impetus for its growth and will open new markets for Chinese products;

3) China's growth model was mainly investment, which in turn led to excess capacity. This excess capacity will be effectively allocated if China enters new markets;

4) China intended to make the yuan an international reserve currency;

5) China's eastern and southern regions are lagging in their development, and the BRI will allow them to correct these regional differences. Regions will have better connection with the world ${ }^{26}$.

${ }^{25}$ Один пояс, один шлях [Електронний ресурс]. - 2017. - Режим доступу до ресурсу: http://sinologist.com.ua/odin-poyas-odin-shlyah-globalnij-geoekonomichnij-proekt-kitayu]: 
"The Silk Road Economic Belt" and "the 21st Century Silk Road" occupy an important place in China's 13th Five Year Plan (2016-2020) and will be determined by the national investment strategy over the period ${ }^{27}$.

In his speech in 2013, the President of the People's Republic of China outlined 5 principles through which joint projects within the "Belt and Road Initiative" can be implemented:

1. Increased political consultation between countries. The Chairman of the People's Republic of China proposed a regular exchange of views on the strategy and tactics of economic development. Guided by the principle of achieving unity of opinion while maintaining differences and through consultations, develop programs and measures for the development of regional cooperation, regional economic integration in political and legal terms.

2. Strengthening the construction of a single transport network. The Chairman of the People's Republic of China also stated China's readiness to consider actively improving cross-border transport infrastructure with all countries in favor of the gradual establishment of a network connecting eastern, western and southern Asia. This will create favorable conditions for economic development and travel for citizens of the countries of the region.

3. Strengthening trade links. The Silk Road economic strip is home to about 3 billion people, and there are huge markets, meaning trade and investment cooperation has great potential. It is advisable to look for adequate trade and investment facilitation schemes, work on elimination of trade barriers, reducing unnecessary trade and investment costs, and increasing the speed and quality of economic transactions.

4. Increase in payments in national currencies. China suggested active switch to national currency payments. The transition to national currencies in exchanges and settlements in current and capital operations will significantly reduce the cost of money transactions, strengthen the economies of countries, prevent financial risks and increase the international competitiveness of the regional economy.

5. Strengthening people-level connections. Interstate relations are based on mutual friendship between peoples, and in order to succeed in cooperation in the above-mentioned areas, it is imperative to have popular support, to strengthen friendly contacts between peoples, to strengthen mutual understanding and traditional friendship. In this way, regional cooperation will gain a strong social and public base.

${ }^{26}$ What is One Belt, One Road in China? [Електронний ресурс]. - 2017. - Режим доступу до ресурсу: https://www.quora.com/What-is-One-Belt-One-Road-in-China

${ }^{27}$ Один пояс, один шлях [Електронний ресурс]. - 2017. - Режим доступу до ресурсу: http://sinologist.com.ua/odin-poyas-odin-shlyah-globalnij-geoekonomichnij-proekt-kitayu/ 
Official documents published by the Ministry of Foreign Affairs of the PRC and the Ministry of Commerce of the PRC emphasize that the "Belt and Road Initiative" goes far beyond the construction of infrastructure. The project will include not only the expansion of cross-border trade and investment, financial integration, but also the internationalization of the yuan, the establishment of links between regional ICT networks and the like ${ }^{28}$. It is noted that the BRI does not contain the idea of creating a free trade area and does not provide for binding agreements between states. Instead, China's intentions to use its economic resources and diplomatic tools are at its core. The use of less formal mechanisms will give the project flexibility and allow Beijing to maximize its economic and political potential.

The BRI project is not so much the result of negotiations, but the result of coordination through consultation, which is a new model of cooperation development. The Chinese government, assessing domestic and international factors in the light of time and circumstances, has proposed a new type of openness strategy, which consists of two important components "complementarity and overall benefit" and "geopolitical considerations" 29.

Many countries in Europe and Asia are interested in it because one of the main obstacles to their economic growth is the underdeveloped transport system.

Under the terms of project financing, China has planned to spend about \$ 1 trillion in investment in various infrastructure projects, while providing loans to low-cost countries through a flexible financing system consisting of the following institutions:

1. The Silk Road Fund (established in 2014, and received US $\$ 40$ billion in funding the same year).

2. Chinese Development Bank.

3. Import and Export Bank of China.

4. New Development Bank (located in Shanghai with registered capital of US $\$ 50$ billion).

5. Asian Investment Infrastructure Bank with 57 founding members (established in 2015 with registered capital of US $\$ 100$ billion) ${ }^{30}$.

Despite Washington's opposition, American allies, including Australia, the United Kingdom, Germany, Italy, the Philippines and South Korea, have

${ }^{28}$ Пятилетнее путешествие Пояса и Пути [Електронний ресурс]. - 2018. - Режим доступу до ресурсу: https://nv.ua/ukr/world/countries/pjatirichna-podorozh-pojasom-i-shljakhom2496956.html

${ }^{29}$ Один пояс, один шлях [Електронний ресурс]. - 2017. - Режим доступу до ресурсу: http://sinologist.com.ua/odin-poyas-odin-shlyah-globalnij-geoekonomichnij-proekt-kitayu/

30 Китайський проект «Один пояс, один шлях» та його можливості для України [Електронний ресурс]. - 2018. - Режим доступу до ресурсу: https:/hvylya.net/analytics/ economics/kitayskiy-proekt-odin-poyas-odin-shlyah-ta-yogo-mozhlivosti-dlya-ukrayini.html 
joined the AIIB, which clearly represents a huge political success for China. Obviously, Beijing's AIIB will give China more independence from the US financial system ${ }^{31}$.

The AIIB budget is in line with Marshall's plan for Europe after the end of World War II. However, this project is not based on a Western model, when leading countries form and manage multilateral institutions, which is underpinned by treaties, international law, and sovereignty. Beijing offers economic opportunities at the level of bilateral relations and regional summits, demonstrating not only the economic recovery of the country, but also the national revival or renewal of the Chinese nation ${ }^{32}$.

Since the beginning of this initiative, the Chinese government has invested over US $\$ 130$ billion abroad (essentially to other countries) ${ }^{33}$.

In May 2017, Beijing hosted the first The Belt and Road International Cooperation Forum, delegations from 100 countries were invited, 29 of which were led by top officials. The purpose of the forum was to coordinate a number of projects that are already being implemented or will be implemented within the initiative. The final communiqué lists 270 of them. Although projects are at different stages of implementation, and some of them even face difficulties due to competition and opposition, it is now possible to say that the Belt and Road initiative already has a clear practical outcome ${ }^{34}$.

The successful implementation of this initiative in the medium and long term should contribute to deepening regional economic integration, expanding cross-border trade and financial flows between Eurasian countries and the outside world, as well as further strengthening the Chinese-oriented trading model, investments and infrastructure. Increasing of energy and mineral resources investment, especially in Central Asia, will help reduce China's dependence on imported commodities from abroad, including oil supplied through the Strait of Malacca ${ }^{35}$.

${ }^{31}$ One Belt - One Road [Електронний ресурс]. - 2017. - Режим доступу до ресурсу: http://www.textilevaluechain.com/index.php/article/industry-general/item/1272-one-belt-one-roadchina-s-big-initiative-creating-massive-business-opportunities-sourced-compiled-by-arvind-sinha

${ }^{32}$ Один пояс, один шлях [Електронний ресурс]. - 2017. - Режим доступу до ресурсу: http://sinologist.com.ua/odin-poyas-odin-shlyah-globalnij-geoekonomichnij-proekt-kitayu/

33 Китайський проект «Один пояс, один шлях» та його можливості для України [Електронний ресурс]. - 2018. - Режим доступу до pecypcy: https://hvylya.net/analytics/ economics/kitayskiy-proekt-odin-poyas-odin-shlyah-ta-yogo-mozhlivosti-dlya-ukrayini.html.

${ }^{34}$ Пятилетнее путешествие Пояса и Пути [Електронний ресурс]. - 2018. - Режим доступу до ресурсу: https://nv.ua/ukr/world/countries/pjatirichna-podorozh-pojasom-i-shljakhom2496956.html]

${ }^{35}$ Один пояс, один шлях [Електронний ресурс]. - 2017. - Режим доступу до ресурсу: http://sinologist.com.ua/odin-poyas-odin-shlyah-globalnij-geoekonomichnij-proekt-kitayu/ 
One of China's goals has already been achieved. As of 2016, the Chinese currency (yuan) has officially entered the list of international reserve currencies, and its impact as of 2018 is estimated at the Eurocurrency level ${ }^{36}$.

The Sino-Pakistan Economic Corridor, which consists of several infrastructure projects in Pakistan worth USD 62 billion, is the most global of the projects implemented.

The main objective is to open a new trade route from the Middle Kingdom (Kashgar) to the Pakistani port of Gwadar (exit to the Arabian Sea).

In 2016, the first batch of Chinese goods was already shipped from Gwadar to Africa. The investment helped modernize Pakistan's existing transportation infrastructure and revitalized the economy, as can be seen in Fig. 3 .

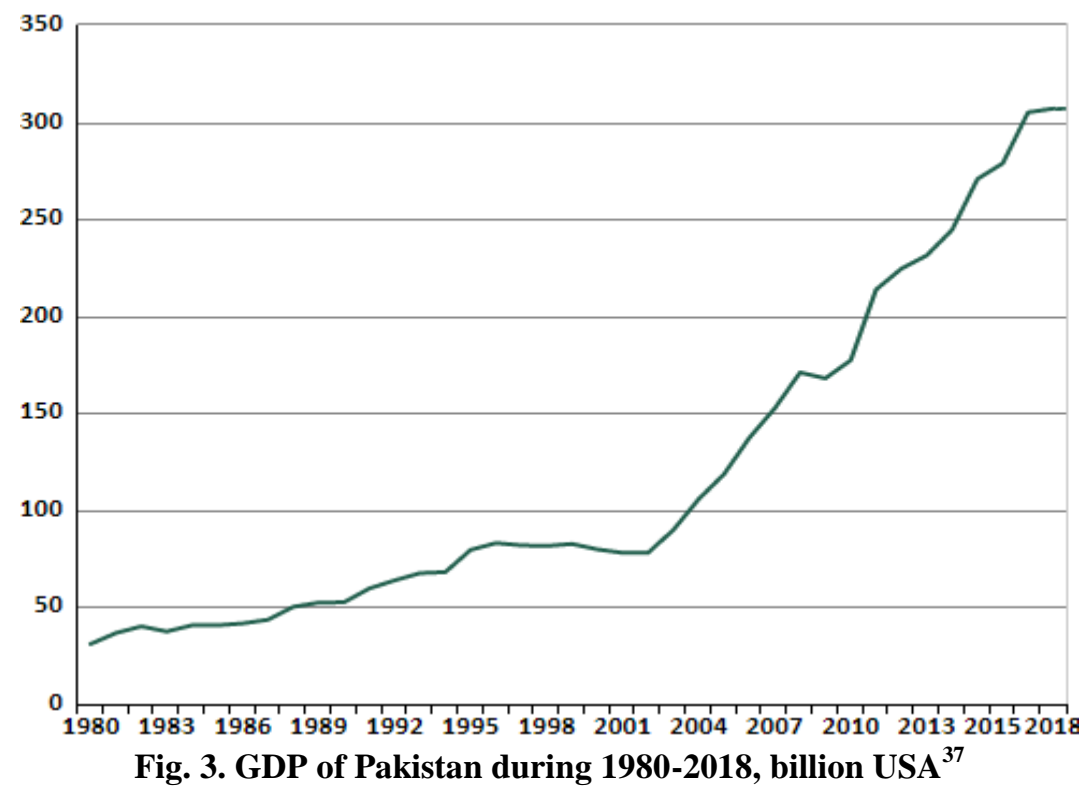

Pakistan's GDP grew from USD 278.66 billion in 2016 to USD 306.9 billion in 2018 .

${ }^{36}$ Евро и юань могут потеснить доллар в глобальной торговле [Електронний ресурс]. 2018. - Режим доступу до ресурсу: https://finance.liga.net/ekonomika/novosti/v-perspektive-dollarmojet-poteryat-mirovoe-gospodstvo---prognoz; Юань став резервною валютою і потіснив євро [Електронний ресурс]. - 2016. - Режим доступу до ресурсу: https://www.dw.com/uk/юань-ставрезервною-валютою-і-потіснив-євро/а-35931655

${ }^{37}$ Пакистан - Валовой внутренний продукт [Електронний ресурс]. - 2019. - Режим доступ до ресурсу: https://knoema.ru/atlas/Пакистан/ВВП 
According to the Pakistani government, this project is expected to create 700,000 working paces for over 10 years and add $2.5 \%$ annually to economic growth by 2030 .

Several projects of less global importance have also been implemented: construction of a power plant in Bangladesh (USD 165 million), replacement of Indonesian slums with modern housing (USD 216.5 million), construction of a hydroelectric power plant in Oman (USD 301 million) ${ }^{38}$.

China and its partner countries have staked on the development of the rail connection between East and West of Eurasia. As of August 26, 2018 the total number of trains from China to Europe and backwards exceeded 10,000 carrying around 800,000 containers of goods. 48 Chinese cities are now connected by routes with 42 cities in 14 countries of Europe. Instead, maritime communication still remains an important trading channel between Asia and Europe, that is why China builds new ports and upgrades old ones in Asia as well as in Europe ${ }^{39}$.

Total trade between China and the countries and regions involved in Belt and Road Initiative exceeded \$ 6 trillion. In 2018, however, China signed 171 cooperation agreements with 29 international organizations and 123 countries, including developed countries as well as developing ones ${ }^{40}$.

For the next step, the ministry is going to launch new collaboration platforms, including the second ${ }^{41}$

Ukraine also expects to take advantage of Chinese platform of the Belt and Road Initiative to strengthen cooperation with PRC in the sphere of transport, communication and infrastructure. This is facilitated by the favorable geographical location of Ukraine at the crossroads of major transit routes between Europe and Asia, the presence of 18 (five of which in the temporarily occupied territory) non-freezing ports of the Black Sea, an extensive network of railways and roads. Today, this is a particularly urgent issue from the point of view of the Association Agreement with the EU and further integration of Ukraine into the transport system of the Europe-Asia-Europe Corridor. The

38 Китайський проект «Один пояс, один шлях» та його можливості для України [Електронний ресурс]. - 2018. - Режим доступу до ресурсу: https://hvylya.net/analytics/ economics/kitayskiy-proekt-odin-poyas-odin-shlyah-ta-yogo-mozhlivosti-dlya-ukrayini.html

${ }^{39}$ Пятилетнее путешествие Пояса и Пути [Електронний ресурс]. - 2018. - Режим доступу до ресурсу: https://nv.ua/ukr/world/countries/pjatirichna-podorozh-pojasom-i-shljakhom2496956.html

${ }^{40}$ China's trade with BRI countries, regions crosses \$6t [Електронний pecypc]. - 2019. Режим доступу до ресурсу: http://www.chinadaily.com.cn/a/201903/06/WS5c7f4742a3106c65 c34ed150.html

${ }^{41}$ Largest exhibition of imported goods and services - "China International Import Expo" [Belt and Road cooperation presents fruitful results [Електронний ресурс]. - 2018. - Режим доступу до ресурсу: http://en.people.cn/n3/2018/0319/c90000-9438950.html. 
largest port of Ukraine is the Port of Odessa which is also the hub of the $9^{\text {th }}$ Trans-European Corridor. It is also worth mentioning the completion of the reconstruction of the Beskid Tunnel, a strategic one from the point of view of the delivery of transit cargo towards the European countries and which is a part of the 5th Pan-European Transport Corridor (Hungary-Slovakia-Ukraine). With all the above mention capabilities Ukraine strives to become a kind of a bridge between Asia and Europe turning the existing potential into a business prospect. Ukraine can offer rail, sea and air services and act as an important transport hub in the process of supplying Chinese goods to European markets and production of home and European producers back to China. Ukraine provides maximum acceptable conditions for cargo transportations through seaports of 58 countries, including the VIKING Train and ZUBR Train transportation services, with help of ferry services of the Trans-Caspian International Corridor ${ }^{42}$.

Thus, the Belt and Road concept can be called a global economic project, because since 2013 it already covers more than 65 countries and consists of two parts: Silk Road Economic Belt and the 21st Century Maritime Silk Road.

\section{CONCLUSIONS}

This study analyzes in detail the free trade agreements signed between China and China in the years 2001-2018 with the following countries: Georgia, Republic of Korea, Iceland, New Zealand, ASEAN, Chile, and Singapore.

It is established that after 2013, China has stepped up its activity to conclude or update its free trade agreements. The main reason, in our view, is the global Chinese One Belt One Way initiative (which began operations in 2013), which envisaged strengthening relations with as many countries as possible.

Overall, in 2019, China announced that it will start reducing or lowering import tariffs for 706 products starting January 1, with the aim of reducing consumer spending. While the first two rounds of tariff cuts in China focused mainly on consumer goods and manufactured goods, the last round affects a wide range of commodities such as cotton, fur, some pharmaceutical raw materials, and will continue to temporarily reduce tariffs on products such as aircraft engines, welding jobs and natural channels.

An in-depth analysis of the concept of "One Belt, One Way" as a strategically important global economic project of China has been carried out, since since 2013 it has already covered more than 65 countries and consists of two parts: "Silk Road Economic Belt" and "21st Century Silk Road".

${ }^{42}$ Asian infrastructure investment bank [Електронний ресурс] // Official website of Asian infrastructure investment bank. - Режим доступу. - URL: http://www.aiib.org 


\section{SUMMARY}

Summarizing the above, we conclude that the current directions of China's foreign trade policy are the introduction of a more active import policy with the simplification of trade procedures, development of new types of trade, promotion of innovative development, creation of a more attractive investment environment, strengthening of the protection of ownership rights., the creation of a new platform for international cooperation "One Belt, One Way" and the creation of new free trade areas

\section{REFERENCES}

1. Висоцька М. Аналіз основних тенденцій розвитку економічних відносин між Україною та Китаєм / М. Висоцька, А. Аль Атті // Стратегія розвитку України. Економіка, соціологія, право. - 2013. - № 4. - С. 14-20, с. 14.

2. China's Free Trade Agreements [Електронний ресурс]. - 2019. Режим доступу до ресурсу: http://fta.mofcom.gov.cn/english/fta_qianshu.shtml

3. Free Trade Agreements under Negotiation [Електронний pecypc]. 2019. - Режим доступу до pесурсу: http://fta.mofcom.gov.cn/english/ fta_tanpan.shtml

4. Asia-Pacific Trade Agreement [Електронний pecypc]. - 2018. Режим доступу до ресурсу: http://fta.mofcom.gov.cn/topic/enpacific.shtml.

5. The 53rd Asia-Pacific Trade Agreement Standing Committee Meeting and Related Panel Meetings Held in South Korea [Електронний pecypc]. - 2018. - Режим доступу до pecypcy: http://fta.mofcom.gov.cn/ enarticle/enpacific/enasiapacificnews/201809/38904_1.html.

6. China-Georgia FTA Comes into Force Today [Електронний pecypc]. - 2018. - Режим доступу до ресурсу: http://fta.mofcom.gov.cn/ enarticle/chinageorgiaen/chinageorgiaennews/201801/36885_1.html.

7. Georgia-China free trade deal comes into play from January 2018 [Електронний ресурс]. - 2018. - Режим доступу до ресурсу: http://agenda.ge/en/news/2018/29

8. China ranks 3rd for Georgia's wine exports in 2018 [Електронний pecypc]. - 2019. - Режим доступу до ресурсу: http://www.xinhuanet.com/ english/2019-01/05/c_137720361.htm.

9. The 2nd Joint Commission on China-ROK FTA Held in Seoul [Електронний ресурс]. - 2018. - Режим доступу до ресурсу: http://fta.mofcom.gov.cn/enarticle/enkorea/enkoreanews/201808/38460_1.html.

10. South Korea's Top Trading Partners [Електронний ресурс]. 2019. - Режим доступу до pecypcy: http://www.worldstopexports.com/southkoreas-top-import-partners/.

11. The 3rd Meeting of Joint Committee of China-Iceland FTA Held in Iceland [Електронний ресурс]. - 2018. - Режим доступу до ресурсу: http://fta.mofcom.gov.cn/enarticle/eniceland/enicelandnews/201809/38980_1.html 
12. Top Iceland Exports [Електронний ресурс]. - 2019. - Режим доступу до pесурсу: http://www.worldsrichestcountries.com/top-iceland-exports.html

13. The 5th Round of Upgrading Negotiation of China-New Zealand Free Trade Agreement Held in Beijing [Електронний ресурс]. - 2018. Режим доступу до ресурсу: http://fta.mofcom.gov.cn/enarticle/ ennewzealand/ ennewzealandnews/201809/38897_1.html

14. New Zealand-China FTA overview [Електронний ресурс]. - 2018. Режим доступу до ресурсу: https://www.mfat.govt.nz/en/trade/free-tradeagreements/free-trade-agreements-in-force/china-fta/nz-china-fta-overview/.

15. The 11th Joint Commission on China-ASEAN FTA Held in Beijing [Електронний ресурс]. - 2018. - Режим доступу до ресурсу: http://fta.mofcom.gov.cn/ enarticle/enasean/chianaseannews/201803/37518_1.html.

16. ASEAN-China trade boosting growth [Електронний ресурс]. 2018. - Режим доступу до pecypcy: http://global.chinadaily.com.cn/a/ 201811/19/WS5bf1f6a6a310eff303289619.html

17. China and ASEAN doing well on economic, trade cooperation [Електронний ресурс]. - 2019. - Режим доступу до ресурсу: https://www.thejakartapost.com/academia/2019/01/31/china-and-asean-doingwell-on-economic-trade-cooperation.html

18. The Protocol Upgrading China-Chile Free Trade Agreement Comes into Force Today [Електронний ресурс]. - 2019. - Режим доступу до ресурсу: http://fta.mofcom.gov.cn/enarticle/enchile/enchilenews/201903/39927_1.html

19. China-Chile FTA Upgraded, New Opportunities for Investors [Електронний ресурс]. - 2019. - Режим доступу до ресурсу: https://www.china-briefing.com/news/china-chile-fta-upgraded-marketopportunities-investors/

20. China and Singapore Sign Protocol to Upgrade the Free Trade Agreement [Електронний pecypc]. - 2018. - Режим доступу до ресурсу: http://fta.mofcom.gov.cn/enarticle/singaporetwoen/singaporetwoennews/20181 1/39360_1.html

21. Biggest fall in Singapore exports in over two years [Електронний pecypc]. - 2019. - Режим доступу до ресурсу: https://www.straitstimes.com/ business/economy/biggest-fall-in-spore-exports-in-over-two-years

22. New Tariff, Export Duty Cuts in China for 2019 [Електронний pecypc]. - 2019. - Режим доступу до pecypcy: https://www.chinabriefing.com/news/new-tariff-export-duty-cuts-china-2019-wide-varietyproducts-affected/

23. What is One Belt, One Road in China? [Електронний ресурс]. 2017. - Режим доступу до ресурсу: https://www.quora.com/What-is-OneBelt-One-Road-in-China 
24. Один пояс, один шлях [Електронний ресурс]. - 2018. - Режим доступу до ресурсу: http://agora-web.jp/archives/2035163.html

25. Один пояс, один шлях [Електронний ресурс]. - 2017. - Режим доступу до ресурсу: http://sinologist.com.ua/odin-poyas-odin-shlyahglobalnij-geoekonomichnij-proekt-kitayu]:

26. Пятилетнее путешествие Пояса и Пути [Електронний ресурс]. 2018. - Режим доступу до pecypcy: https://nv.ua/ukr/world/countries/ pjatirichna-podorozh-pojasom-i-shljakhom-2496956.html

27. One Belt - One Road [Електронний ресурс]. - 2017. - Режим доступу до ресурсу: http://www.textilevaluechain.com/index.php/article/ industry-general/item/1272-one-belt-one-road-china-s-big-initiative-creatingmassive-business-opportunities-sourced-compiled-by-arvind-sinha

28. Китайський проект «Один пояс, один шлях» та його можливості для України [Електронний ресурс]. - 2018. - Режим доступу до ресурсу: https://hvylya.net/analytics/economics/kitayskiy-proekt-odin-poyas-odinshlyah-ta-yogo-mozhlivosti-dlya-ukrayini.html.

29. Евро и юань могут потеснить доллар в глобальной торговле [Електронний ресурс]. - 2018. - Режим доступу до ресурсу: https://finance.liga.net/ ekonomika/novosti/v-perspektive-dollar-mojet-poteryatmirovoe-gospodstvo---prognoz; Юань став резервною валютою і потіснив євро [Електронний ресурс]. - 2016. - Режим доступу до ресурсу: https://www.dw.com/uk/юань-став-резервною-валютою-і-потіснив-євро/a35931655

30. Пакистан - Валовой внутренний продукт [Електронний ресурс]. 2019. - Режим доступ до ресурсу: https://knoema.ru/atlas/Пакистан/ВВП

31. China's trade with BRI countries, regions crosses $\$ 6 t$ [Електронний pecypc]. - 2019. - Режим доступу до ресурсу: http://www.chinadaily.com.cn/ a/201903/06/WS5c7f4742a3106c65c34ed150.html

32. largest exhibition of imported goods and services - "China International Import Expo" [Belt and Road cooperation presents fruitful results [Електронний ресурс]. - 2018. - Режим доступу до ресурсу: http://en.people.cn/n3/2018/0319/c90000-9438950.html.

33. Asian infrastructure investment bank [Електронний ресурс] // Official website of Asian infrastructure investment bank. - Режим доступу. URL: http://www.aiib.org

\section{Information about the author:}

Korol M. M.,

$\mathrm{PhD}$ in Economics,

Associate Professor at the International Economic Relations Department,

Uzhhorod National University 14, Universytetska str., Uzhhorod, 88000, Ukraine 